F. Reprod. Fert. (1970) 23, 263-269

\title{
IMMUNOLOGICAL STUDIES WITH RAT TESTIS: ANTIGENIC CHARACTERIZATION
}

\author{
K. P. GUNAGA, A. R. SHETH AND SHANTA S. RAO \\ Institute for Research in Reproduction (ICMR), Fehangir Merwanji Street, \\ Parel, Bombay 12, India
}

(Received 11th November 1969)

\begin{abstract}
Summary. Testes of Wistar rats contain at least three organ-specific antigens as revealed by the gel diffusion analysis. Antiserum to rat testis absorbed with serum and liver cross-reacts with the extracts of epididymis, brain and ovary. Heating at over $60^{\circ} \mathrm{C}$ destroys the combining power of all the three testis-specific antigens. Two of the three organspecific antigens of the Wistar strain of rats are common to two antigens present in the testes of man, sheep, rabbit, hamster, guinea-pig and mouse.
\end{abstract}

\section{INTRODUCTION}

Voisin, Delaunay \& Barber (1951) first reported the occurrence of testicular lesions resulting from the immunization of guinea-pigs with homologous testicular extract and later, Freund, Lipton \& Thompson (1954) observed that aspermatogenesis resulted when rats were repeatedly injected with homologous testicular extract mixed with Freund's adjuvant. Tyler (1961) and Rao (1964) have comprehensively reviewed the earlier work on induction of infertility in rats with homologous testicular tissue. Segal (1963) reported the presence of common antigens between rat testes, prostate, kidney and adrenal.

The work reported here pertains to the antigenic analyses of rat testis as well as to the study of the antigens which the testis has in common with the accessory glands of reproduction, other vital organs and the gonads of the homologous female. Attempts have also been made to separate the testis-specific antigens.

\section{MATERIALS AND METHODS}

\section{Preparation of the antiserum to rat testis extract}

The testes of adult rats were homogenized in saline $(100 \mathrm{mg}$ tissue $/ \mathrm{ml})$ and centrifuged at $300 \mathrm{~g}$ for $15 \mathrm{~min}$. This type of clarified extract was the material used as an antigen. A $0.5-\mathrm{ml}$ volume of the homogenate mixed with an equal volume of Freund's adjuvant was injected into three rabbits once every week. The rabbits were bled 5 to 6 days after the fifth injection and the sera were separated.

\section{Removal of non-specific antigens}

Antiserum to testes was absorbed with normal rat serum and liver in the 
following manner. To $10 \mathrm{ml}$ of rabbit antiserum to rat testis was added $50 \mathrm{mg}$ of lyophilized rat serum. This was incubated for $30 \mathrm{~min}$ at $37^{\circ} \mathrm{C}$ and then stored at $5^{\circ} \mathrm{C}$ overnight. At the end of this time, the absorbed antiserum was centrifuged at $300 \mathrm{~g}$ for $30 \mathrm{~min}$ to separate the precipitate. The absorption procedure with lyophilized serum was repeated till no further precipitate was formed. This antiserum, from which antibodies to blood serum were removed, was further absorbed with acetone-dried, normal rat liver powder. The antiserum so absorbed did not give a cross reaction with homogenates of liver and most of the other organs. Isojima \& $\mathrm{Li}(1968)$ have also made a similar observation.

\section{Separation of testicular antigen on a Sephadex column}

The testicular extract (686 mg protein) was passed through a column of Sephadex G-200 $(2.5 \times 60 \mathrm{~cm})$ prepared in water and later equilibrated by passing 2 litres of $0.05 \mathrm{M}-\mathrm{NaCl}$. The fractions were eluted with $0.05 \mathrm{~m}-\mathrm{NaCl}$.

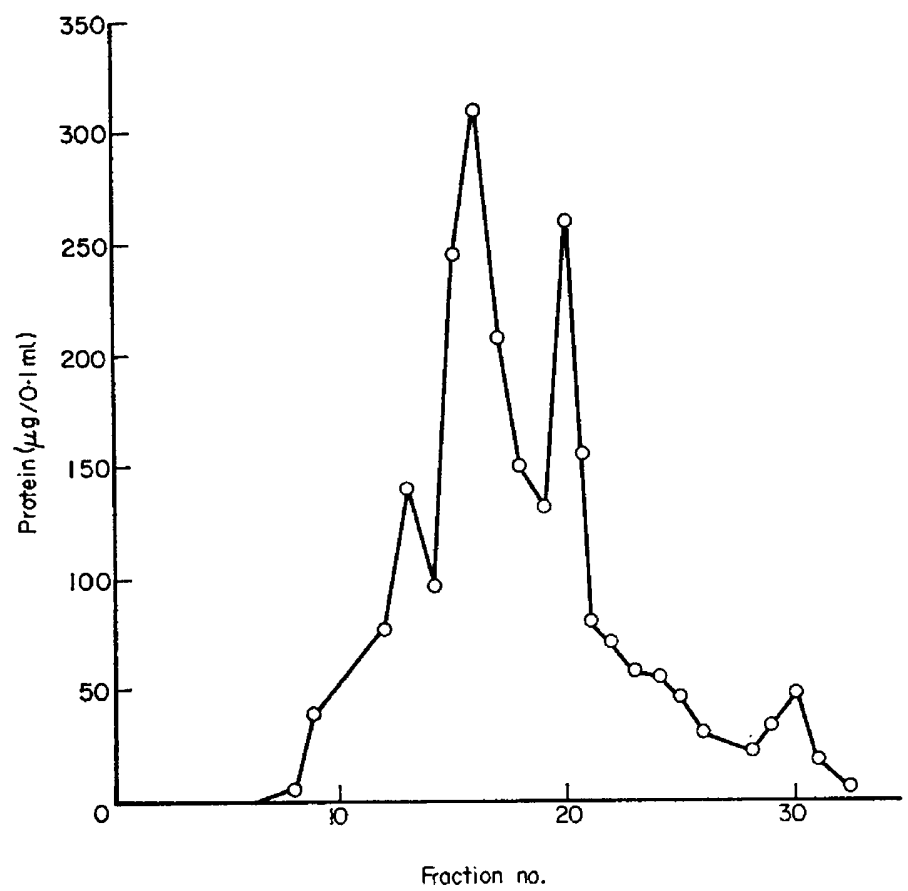

Text-Fig. 1. Chromatographic fractionation of the saline soluble component of rat testes.

The entire fractionation procedure was carried out between $5^{\circ}$ and $7^{\circ} \mathrm{C}$ and 6-ml aliquots were collected at intervals of $30 \mathrm{~min}$. The protein concentration in the individual fractions was determined by the method of Lowry, Rosebrough, Farr \& Randall (1951). The pattern indicated that at least four peaks of protein were eluted (Text-fig. 1). The fractions were pooled as follows: Tubes 8 to 13 (Fraction A), Tubes 14 to 17 (Fraction B), Tubes 18 to 21 (Fraction $\mathrm{C}$ ) and Tubes 22 to 32 (Fraction D). 
Antigens used

All rat organs used for immunological work were homogenized in saline (10 $\mathrm{mg}$ protein $/ \mathrm{ml}$ ). Seminiferous tubules from the testes were collected according to the method of Christensen \& Mason (1965). Tubules with adhering interstitial tissue, as observed under the dissection microscope, were discarded.

The ovine luteinizing and follicular stimulating hormones (NIH-LH-s7 and NIH-FSH-s2) used in the experiments were obtained from the Endocrinology Study Section, NIH, Bethesda, Maryland, U.S.A. Rat pituitary gonadotrophin was prepared in the laboratory according to the method of Koenig \& King (1950). The human chorionic gonadotrophin used was from Leo Pharmaceuticals, Copenhagen. The Wistar and Holtzman strain of rats used were from inbred strains maintained in our animal colony. The albino and cotton rats were random-bred strains obtained from the Haffkine Institute, Bombay.

\section{Immuno-diffusion and immuno-electrophoresis}

The agar gel diffusion method of Ouchterlony (1949) was employed for these studies. Immuno-electrophoresis was essentially carried out by the method of Grabar (1964). Hydrazone agar was used for immuno-electrophoresis as the work carried out in our laboratory has revealed that the treated agar gives better separation of the seminal plasma proteins of man (Kalelkar, Gunaga, Sheth \& Rao, 1967).

\section{Heat stability}

The heat stability of the testis-specific antigen was determined by maintaining the testicular extract, as well as Fraction $\mathrm{B}$, at $60^{\circ}, 80^{\circ}$ and $100^{\circ} \mathrm{C}$ for $15 \mathrm{~min}$. These were then centrifuged and the supernatants were used for immunoanalyses.

\section{RESULTS}

As can be observed in PI. 1, Fig. 1, the testicular extract gave three precipitin lines with the antisera obtained from three different rabbits. Experiments were performed to find out whether the number of precipitin lines diminished on dilution of the antigens. The results revealed that the $10 \%$ homogenate gave three distinct precipitin lines (Pl. 1, Fig. 2). These lines became fainter when lower dilutions of the extract were used.

The results of the Ouchterlony gel diffusion technique using absorbed and unabsorbed antiserum are presented in Table 1. The extracts of all the organs used for the antigenic analyses contained the same amount of protein (10 $\mathrm{mg} / \mathrm{ml}$ ). It was noted that the antiserum to rat testes after absorption with serum and liver powder gave three precipitin lines with testicular extract, two with epididymal extract, and one each with the extract of brain and ovaries (Pl. 1, Figs. 3a, b). Extract of no other tissue gave a visible precipitin line with the absorbed antiserum. Gonadotrophins from different sources, namely rat and sheep pituitaries and human chorion, failed to react with the absorbed antiserum. 
It was of interest to study the antigenic composition of interstitial cells, seminiferous tubules and tunica albuginea. The results revealed that only the extract of seminiferous tubules gave two precipitin lines with absorbed antiserum ( $\mathrm{Pl}$. 1, Figs. 4a, b). It thus appeared that the testis-specific antigens were contributed mainly by the seminiferous tubules.

The testicular extract was subjected to immuno-electrophoresis in order to explore the possibility of obtaining a further resolution of the components of the extract. Two precipitin lines appeared in the $\gamma$-globulin region, whereas

TABLE 1

RESULTS OF THE OUCHTERLONY GEL DIFFUSION TEST WITH DIFFERENT ANTIGENS AGAINST RABBIT ANTISERUM TO RAT TESTIS

\begin{tabular}{|c|c|c|c|}
\hline \multirow{2}{*}{ Organ } & \multicolumn{3}{|c|}{ No. of antigen-antibody precipitin lines } \\
\hline & $\underset{\text { absorbed }}{U n-}$ & $\begin{array}{l}\text { Absorbed with } \\
\text { serum }\end{array}$ & $\begin{array}{l}\text { Absorbed with } \\
\text { serum and liver }\end{array}$ \\
\hline $\begin{array}{l}\text { Testis } \\
\text { Rat serum } \\
\text { Rabbit serum } \\
\text { Epididymis } \\
\text { Seminal vesicles } \\
\text { Ventral prostate } \\
\text { Dorsal prostate } \\
\text { Coagulating glands } \\
\text { Brain } \\
\text { Pituitary } \\
\text { Heart } \\
\text { Liver } \\
\text { Spleen } \\
\text { Kidney } \\
\text { Adrenal } \\
\text { Lung } \\
\text { Intestine } \\
\text { Muscle } \\
\text { Ovary } \\
\text { Uterus } \\
\text { Vagina }\end{array}$ & $\begin{array}{l}8 \\
3 \\
6 \\
3 \\
4 \\
4 \\
4 \\
4 \\
3 \\
4 \\
5 \\
5 \\
5 \\
3 \\
4 \\
2 \\
5 \\
4 \\
\end{array}$ & $\begin{array}{l}\frac{5}{3} \\
\frac{3}{1} \\
1 \\
\frac{1}{2} \\
\frac{1}{2} \\
\frac{2}{2} \\
\frac{1}{2} \\
\frac{1}{2}\end{array}$ & $\begin{array}{l}\frac{3}{2} \\
\frac{2}{E} \\
\frac{1}{E} \\
= \\
= \\
= \\
= \\
\frac{1}{-}\end{array}$ \\
\hline
\end{tabular}

Antigen concentration: $10 \mathrm{mg}$ protein $/ \mathrm{ml}$.

\section{EXPLANATION OF PLATE 1}

Fig. 1. Gel diffusion precipitation pattern. Centre wells: T, saline extract of rat testis $(10 \mathrm{mg}$ protein $/ \mathrm{ml})$. Side wells : rabbit antiserum to rat testis. $A_{1}$, Unabsorbed antiserum from rabbit No. I. $\mathbf{A}_{2}$, unabsorbed antiserum from rabbit No. II. $\mathbf{A}_{3}$, unabsorbed antiserum from rabbit No. III. $A b_{1}$, absorbed antiserum from rabbit No. I. $A b_{2}$, absorbed antiserum from rabbit No. II. $\mathrm{Ab}_{3}$, absorbed antiserum from rabbit No. III.

Fig. 2. Gel diffusion precipitation pattern. Centre wells: saline extract of rat testis. $T_{1}, 10 \%$ saline extract. $T_{2}, 5 \%$ saline extract. $T_{3}, 2.5 \%$ saline extract. $T_{4}, 1 \%$ saline extract. Side wells: rabbit antiserum to rat testis. $\mathrm{A}_{1}$, unabsorbed antiserum. $\mathrm{A}_{2}$, antiserum absorbed with serum and liver.

Fras. 3a, b. Gel diffusion precipitation pattern. Centre wells: rabbit antiserum to rat testis. $A_{1}$, unabsorbed. $A_{2}$, absorbed with rat serum. $A_{3}$, absorbed with rat serum and liver. Side wells: saline extracts of rat organs. $T$, testicular extract. $O$, ovarian extract. E, epididymal extract. $B$, brain extract.

Figs. 4a, b. Gel diffusion precipitation pattern. Centre wells: rabbit antiserum to rat testis. $A_{1}$, unabsorbed. $A_{2}$, absorbed with rat serum. $A_{3}$, absorbed with rat serum and liver. Side wells: saline extracts of rat organs. $T$, testis. S, seminiferous tubules. I, interstitial cells. TU, tunica albuginea. 

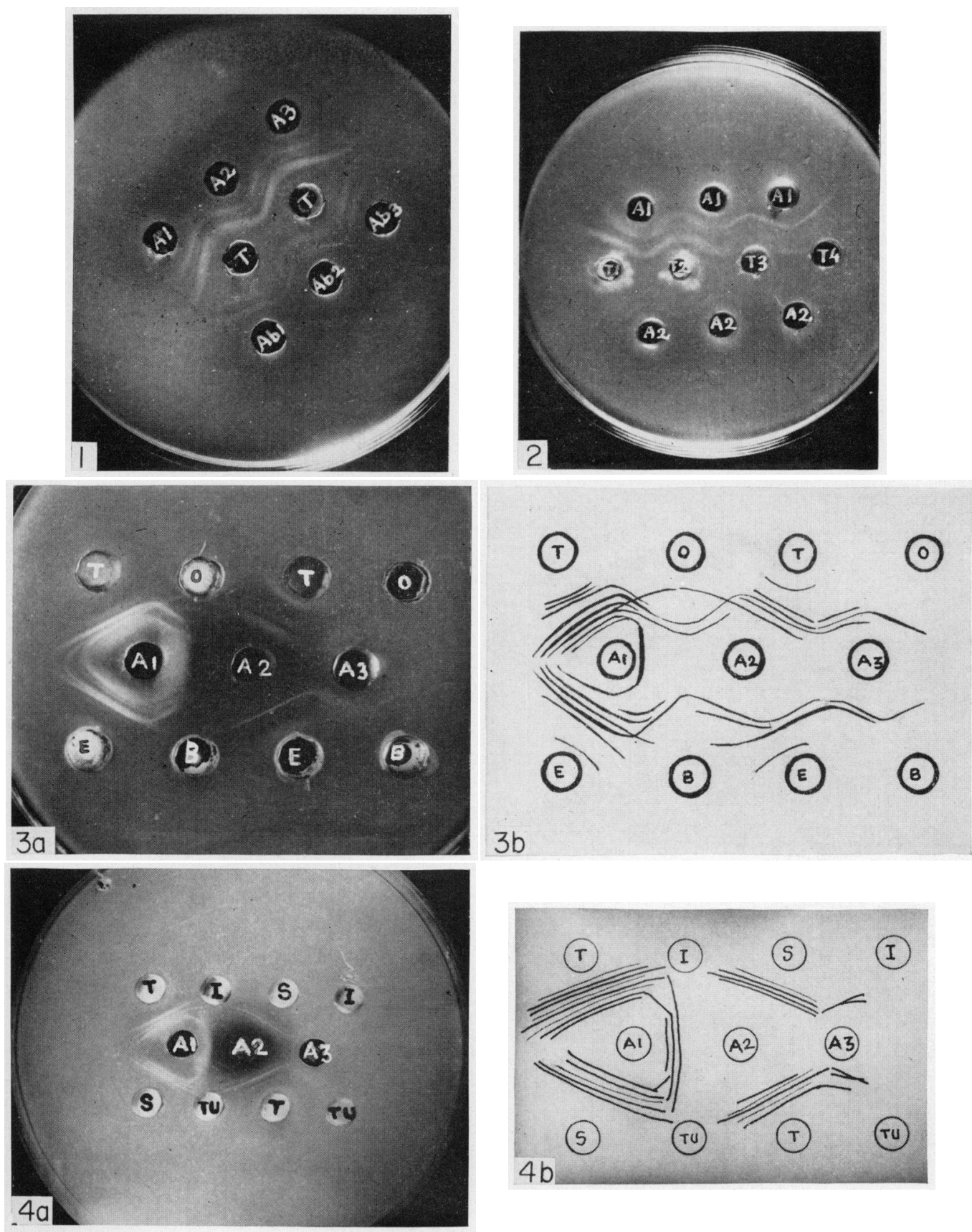

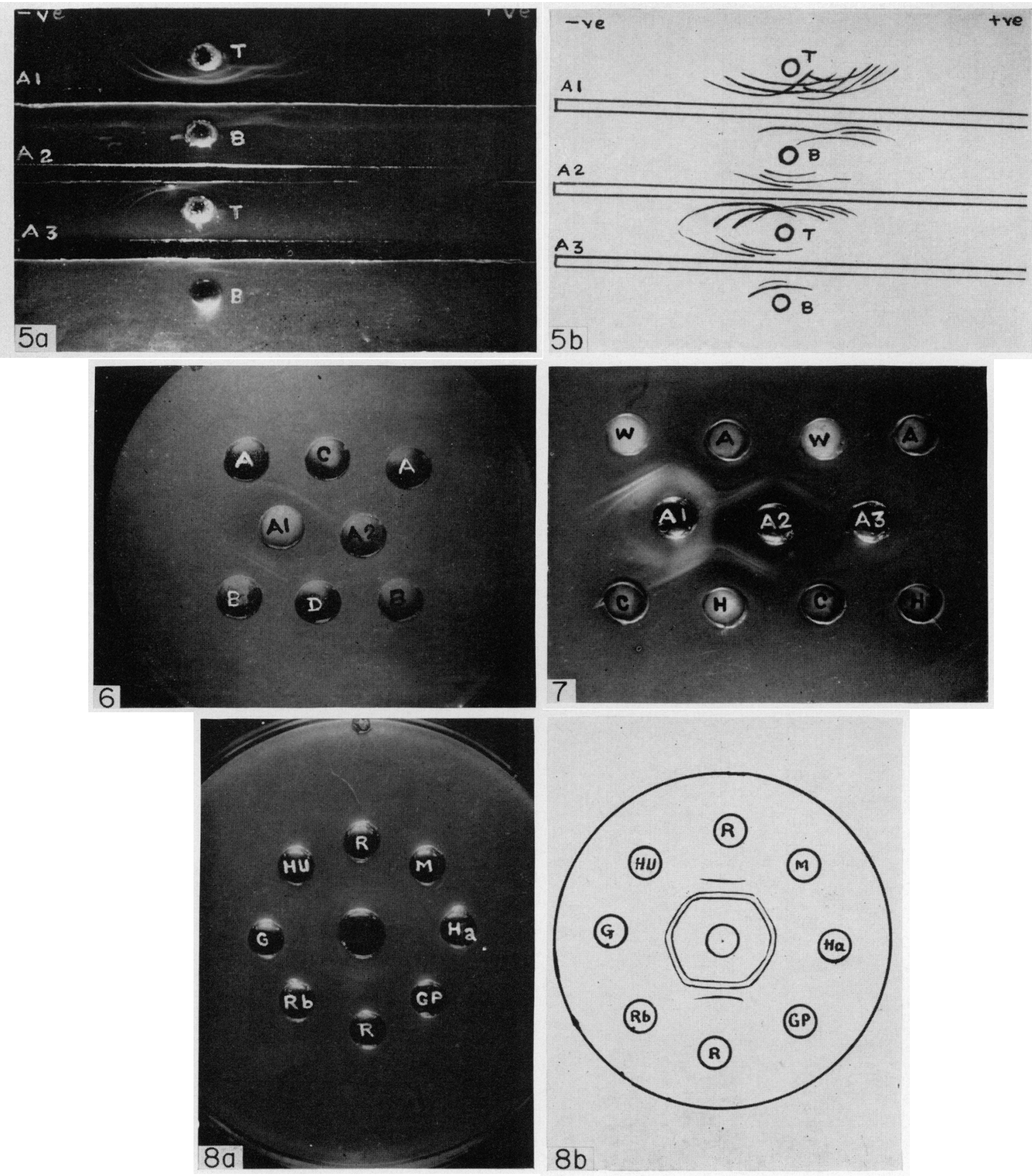
only one precipitin line appeared in the $\beta$-globulin region (Pl. 2, Figs. 5a, b). In addition, Fraction $B$ also had an antigen which gave a cross-reaction with the antigen present in the homologous liver extract (Pl. 2, Fig. 6).

It was observed that heating at temperatures above $60^{\circ} \mathrm{G}$ destroyed the combining power of the testicular antigens (Table 2).

TABLE 2

RESULTS OF THE OUCHTERLONY GEL DIFFUSION TEST WITH RAT TESTICULAR EXTRAGT AND FRACTION B HEATED AT DIFFERENT TEMPERATURES AGAINST RABBIT ANTISERUM TO RAT TESTIS ABSORBED WITH SERUM AND LIVER

\begin{tabular}{|c|c|c|}
\hline \multirow{2}{*}{$\begin{array}{c}\text { Temperature } \\
\left({ }^{\circ} \mathrm{C}\right)\end{array}$} & \multicolumn{2}{|c|}{ No. of antigen-antibody precipitin lines } \\
\hline & Testis & Fraction $B$ \\
\hline $\begin{array}{r}30 \\
60 \\
80 \\
100\end{array}$ & $\begin{array}{c}3 \\
3 \\
\mathrm{Nil} \\
\mathrm{Nil}\end{array}$ & $\begin{array}{c}2 \\
2 \\
\mathrm{Nil} \\
\mathrm{Nil}\end{array}$ \\
\hline
\end{tabular}

The strain specificity of the testis-specific antigens was studied using rats of two different inbred strains (Wistar and Holtzman) and two random-bred strains (albino and cotton rat). It was observed that the antigens present in the testes of the Wistar strain of rats were also present in those of albino rats from the Haffkine Institute and Holtzman strains. The testis of the cotton rat, however, failed to give any precipitin line with the absorbed antiserum (Pl. 2, Fig. 7).

The species specificity of the testicular antigens was also examined. The antiserum to rat testes gave cross-reactions with the testicular antigens of man, sheep, rabbit, hamster, guinea-pig and mouse (Pl. 2, Figs. 8a, b).

\section{DISCUSSION}

The present investigations indicate that the rat testicular tissue has three antigens. These observations are similar to those made in our laboratory with mouse testicular extracts (Sadri, Shetye \& Rao, 1967). Segal (1963) reported

\section{EXPLANATION OF PLATE 2}

Fics. 5a, b. Immuno-electrophoresis. Antiserum troughs: rabbit antiserum to rat testis. $A_{1}$, unabsorbed. $A_{2}$, absorbed with rat serum. $A_{3}$, absorbed with rat serum and liver. Antigen wells: T, Saline extract of rat testis. B, Fraction B obtained from Sephadex G-200 column.

Fig. 6. Gel diffusion precipitation pattern. Gentre wells: Rabbit antiserum to rat testis. $A_{1}$, absorbed with rat serum. $A_{2}$, absorbed with rat serum and liver. Side wells: testicular fraction obtained from Sephadex G-200 column. A, B, C, D denote various fractions.

Frg. 7. Gel diffusion precipitation pattern. Centre wells: rabbit antiserum to rat testis. $A_{1}$, unabsorbed. $A_{2}$, absorbed with rat serum. $A_{3}$, absorbed with rat serum and liver. Side weils: saline extracts of testes of rats of different strains. W, Wistar. H, Holtzman. A, Albino. C, Cotton.

FIGs. 8a, b. Gel diffusion precipitation pattern. Centre well: rabbit antiserum to rat testis absorbed with rat serum and liver. Peripheral wells: saline extracts of testis. $R$, rat. $M$, mouse. GP, guinea-pig. $H a$, hamster. $R b$, rabbit. $G$, goat. Hu, human. 
that rabbit antiserum to rat testis gave immunological reactions with the prostate, kidney and adrenals but none with other visceral organs.

The results reported in this communication have indicated that the antiserum to rat testes absorbed with serum and liver tissue gave a cross-reaction with epididymis, brain and ovary. Lewis (1933) reported the presence of a common antigen between brain and testis.

It was of interest to note that the testis and the ovary have an antigen in common. A similar observation was made by Shahani, Padbidri \& Rao (personal communication) using an antiserum to ratovarian tissue. Paine \& Behrman (1968) carried out active immunization of female guinea-pigs with homologous testicular tissue. Using immunofluorescence, they were able to demonstrate that anti-testis antibodies were localized in the vagina, cervix, uterus and spleen but were unable to detect the fixation of antibodies in the oviduct and ovary. On the basis of these results, they postulated that the testis, uterus, vagina and cervix may have similar or identical components. The present findings indicate that the testis and the ovary have a common antigen but it was not possible to demonstrate a common antigen between the testis and vaginal tissue, even on repeated testing.

The antigens present in rat testes were destroyed at temperatures above $60^{\circ} \mathrm{C}$. Similar results were observed in the case of antigens of human seminal plasma and spermatozoa (Rao, Sadri \& Sheth, 1960). Milgrom, Maide, Tugga \& Witebsky (1965) found that organ-specific antigens of liver, testis and pituitary of bulls are heat stable. It should be noted, however, that these workers extracted the tissues at $100^{\circ} \mathrm{C}$ followed by precipitation by a $72 \%$ concentration of ethanol. It is likely that the antigens extracted by different procedures are not identical. The comparative analyses of the antigens of human, goat, rabbit, guinea-pig, hamster and mouse testis have revealed that two antigens are common to the testes of the species used in the present study. Katsh \& Bishop (1958) reported cross-reactivity between guinea-pig and human spermatozoa. This was based on the observation that the testes of some of the male guineapigs immunized with human spermatozoa were damaged.

The testes of rats of the Wistar, albino and Holtzman strains have three antigens in common, whereas that of the cotton rat failed to give any visible precipitin lines with the antiserum absorbed with serum and liver.

\section{ACKNOWLEDGMENTS}

The equipment donated to the Reproductive Physiology Unit by the World Health Organization and the Rockefeller Foundation was of great use in carrying out the research reported.

\section{REFERENCES}

GHristensen, A. K. \& Mason, N. R. (1965) Comparative ability of seminiferous tubules and interstitial tissue of rat testes to synthesize androgen from progesterone-4-14 $\mathrm{C}$ in vitro. Endocrinology, 76, 646.

Freund, J., Lipton, M. M. \& Thompson, G. E. (1954) Impairment of spermatogenesis in the rat after cutaneous injection of testicular suspension with complete adjuvants. Proc. Soc. exp. Biol. Med. 87, 408. 
GRABAR, P. (1964) The immunoelectrophoretic method of analysis. In: Immunoelectrophoretic Analysis, pp. 3-29. Eds. P. Grabar and P. Burtin. Elsevier Publishing Company, Amsterdam.

Isojima, S. \& Lr, T. S. (1968) Stepwise appearance of sperm-specific antigens in rats and their disappearance after fertilization. Fert. Steril. 19, 999.

Kalelrar, Y. M., Gunaga, K. P., Sheth, A. R. \& Rao, S. S. (1967) Physico-chemical and antigenic characterization of human seminal plasma proteins. Part II. Biochemical characterization of the trichloroacetic acid soluble component of human seminal plasma. Indian Jnl Biochem. 4, 100.

Katsh, S. \& Bishop, D. W. (1958) The effects of homologous testicular and brain and heterologous testicular homogenates combined with adjuvant upon the testes of guinea-pigs. F. Embryol. exp. Morph. 6, 94.

Koenig, V. L. \& KING, E. (1950) Extraction studies of sheep pituitary gonadotrophin and lactogenic hormones in alcoholic acetate buffers. Archs Biochem. 26, 219.

LewIs, J. M. (1933) The immunologic specificity of brain tissue. J. Immunol. $24,193$.

Lowry, O. H., Rosebrough, N. J., Farr, A. L. \& Randall, R. J. (1951) Protein measurement with the Folin phenol reagent. $\mathcal{F}$. biol. Chem. 193, 265.

Milgrom, F., Maide, Z., Tugga, C. \& Wrtebsky, E. (1965) Organ specific antigens of liver, testicle and pituitary. F. Immunol. 94, 157.

Ouchterlony, O. (1949) Antigen-antibody reactions in gels. Acta path. microbiol. scand. $26,507$.

Paine, P. J. \& Behrman, S. J. (1968) Antibody localization in guinea-pig reproductive tissue. Int. $\mathcal{F}$. Fert. 13, 121.

Rao, S. S. (1964) The study and control of reproduction by immunological methods. F. Scient. Ind. Res. 23, 337.

RAo, S. S., SADri, K. K. \& Sheth, A. R. (1960) The antigenicity of human spermatozoa and its significance. Proc. Symp. on Proteins, pp. 218-225. Pub. Central Food Technological Research Institute (1961).

Sadri, K. K., Shetye, T. A. \& Rao, S. S. (1967) Immunological and biological studies with antiserum to mouse testes extract. Indian J. exp. Biol. 5, 122.

Segal, S. J. (1963) Cited by Tyler, A. \& Bishop, D. W. (1963) Immunological phenomena. In: Mechanism Concerned with Conception, pp. 397-482. Ed. C. G. Hartman. Pergamon Press, Oxford.

Tyler, A. (1961) Approaches to the control of fertility based on immunological phenomena. $\mathcal{F}$. Reprod. Fert. 2, 473.

Voisin, G. A., Delaunay, A. \& Barber, M. (1951) Sur des lésions testiculaires provoqueés chez le cobaye par iso- et auto-sensibilisation. Annls Inst. Pasteur, Paris, 81, 48. 